\title{
Artificial Fe-Type Zeolite Enhances Methane Production in Anaerobic Digestion under Ammonium-Rich Conditions
}

\author{
CHIKA TADA ${ }^{1}$, SHIGERU HAYASHIBARA ${ }^{2}$, YOUICHI UTATSU ${ }^{2}$, and SHIGEKI SAWAYAMA ${ }^{3 *}$ \\ ${ }^{1}$ Biomass Technology Research Center, National Institute of Advanced Industrial Science and Technology \\ / 16-1, Onogawa, Tsukuba, 305-8569, Japan \\ (current; Department of Bioresorce Technology, Okinawa National College of Technology \\ / 905 Henoko, Nago, 905-2192, Japan.) \\ ${ }^{2}$ Environment Group, Engineering Department, Maeda Corporation, Ltd. \\ / 2-10-26, Fujimi, Chiyoda-ku, Tokyo, 102-8151, Japan \\ ${ }^{3}$ Biomass Technology Research Center, National Institute of Advanced Industrial Science and Technology \\ / 2-2-2, Hirosuehiro, Kure, 737-0197, Japan
}

\begin{abstract}
In this study, the effects of Fe-type, Ca-type, and low-sodium-level Ca-type artificial zeolites, made from waste coal ash, on methane production and the methanogen communities under ammonium-rich conditions were investigated. Methane production with Fe-type zeolite was higher than that with the other types of zeolites, and was about four times higher than that without zeolite. Acetate was not accumulated during anaerobic digestion of ammonium-rich organic waste with Fe-type zeolite. The methanogen community which were analysed by real-time polymerase chain reaction (PCR) with Fetype zeolite was almost the same as that with Ca-type zeolite. These results showed that quantities of methanogen have not relation with the volume of methane production. A comparison of methane production with $\mathrm{Fe}$-type zeolite and that with $\mathrm{Fe}$ ions or $\mathrm{Ca}$ ions in anaerobic digestion under ammonium-rich conditions confirmed that Fe-type zeolite was the most effective in enhancing methane production, $\mathrm{Ca}$ ions addition was not enhancing the methane production contrary. Fe-type zeolite is considered to play two roles in anaerobic digestion; namely, supplying iron to the anaerobic microbes, and decreasing the ammonium concentration.
\end{abstract}

Keywords: Ammonium, Anaerobic digestion, Artificial zeolite, Fe, Methane

\section{INTRODUCTION}

Anaerobic digestion of organic wastes has the advantages of relatively low sludge production, low energy consumption, and methane production, with the result that this process is widely studied and used ${ }^{11}$. Organic waste usually contains nitrogenous compounds such as proteins, which are converted to ammonium by anaerobic digestion. Inhibition of anaerobic digestion of organic wastes, such as from livestock and dewatered sewage sludge, is often caused by a high ammonia concentration ${ }^{2-4)}$. A high $\mathrm{NH}_{4}^{+}$concentration is toxic for anaerobes ${ }^{5-7)}$. McCarty reported that $\mathrm{NH}_{4}{ }^{+}-\mathrm{N}$ concentrations in excess of 3000 $\mathrm{mg} / \mathrm{l}$ could be expected to be toxic at any $\mathrm{pH}$ value $^{8}$. Hobson and Shaw reported that 235 mmol $\quad(3290 \quad \mathrm{mg} \quad \mathrm{N} / \mathrm{l}) \quad \mathrm{NH}_{4}{ }^{+}$completely prevented the growth of Methanobacterium formicicum in pure culture ${ }^{9}$.

To avoid $\mathrm{NH}_{4}^{+}$inhibition, organic wastes are usually diluted with water and carbonrich materials before digestion; however, dilution requires a large reactor and increases the cost of treatment. For this reason, $\mathrm{NH}_{4}{ }^{+}$

*Corresponding author 
removal during anaerobic digestion is necessary for efficient digestion of waste having a relatively high organic concentration.

Other than dilution studies, there are only a few reports on reducing ammonia inhibition; for example, the magnesium ammonium phosphate (MAP) process $^{10)}$ and the lighted upflow anaerobic sludge blanket method ${ }^{11}$. Some zeolites and clays are able to absorb $\mathrm{NH}_{4}{ }^{+}$by cation exchange reaction, and several papers have reported on the application of zeolite and clay to reduce inhibition by ammonia during anaerobic digestion ${ }^{12-14}$. Angelidaki et al. (1993) used bentonite clay for anaerobic thermophilic digestion of cattle manure ${ }^{13)}$. Milan et al. (2001) used a natural zeolite, consisting of a mixture including clinoptilolite, mordenite, and montmorillonite, for the anaerobic digestion of piggery waste ${ }^{12}$. Hansen et al. (1999) used glauconite for the anaerobic digestion of swine manure ${ }^{14)}$. Tada et al. (2005) reported that natural mordenite enhanced methane production in ammoniumrich organic waste during anaerobic digestion, and that $\mathrm{Ca}$ ions released from the natural mordenite had the effect of improving methane production under ammonium-rich conditions ${ }^{15}$. These studies revealed that the addition of clay and zeolite improved methane production; however, the mechanism by which zeolite enhances anaerobic digestion has not yet been actively discussed.

In this study, several types of artificial zeolite made from waste coal ash were used to investigate the effects of zeolites on methane production and the archaeal community under ammonium-rich conditions.

\section{MATERIALS AND METHODS}

2.1 Seed sludge and zeolites Anaerobically digested and dewatered sludge was collected from a sewage treatment plant in Ibaraki Prefecture, Japan, and stored at $4^{\circ} \mathrm{C}$. The sludge was mixed with distilled water and stirred anaerobically for 10 days at room temperature before being used as the seed sludge for the anaerobic digestion.

Three types of artificial zeolites, Fe-type, Ca-type, and low-sodium-level Ca-type, made from waste coal ash (Maeda Co., Ltd., Tokyo,
Table 1 Properties of the artificial zeolites used in the experiments

\begin{tabular}{lrrrrr}
\hline & $\mathrm{pH}$ & $\begin{array}{c}\mathrm{CEC} \\
(\mathrm{cmol} / \mathrm{kg})\end{array}$ & $\begin{array}{c}\mathrm{Na} \\
(\mathrm{cmol} / \mathrm{kg})\end{array}$ & $\begin{array}{c}\mathrm{K} \\
(\mathrm{cmol} / \mathrm{kg})\end{array}$ & $\begin{array}{c}\mathrm{Ca} \\
(\mathrm{cmol} / \mathrm{kg})\end{array}$ \\
\hline Fe-type zeolite & 8.9 & 240 & 83 & 14 & 229 \\
Ca-type zeolite & 10.0 & 258 & 109 & 17 & 310 \\
$\begin{array}{l}\text { Low sodium level } \\
\text { Ca-type zeolite }\end{array}$ & 9.8 & 258 & 32 & 11 & 285 \\
\hline
\end{tabular}

Japan) and supplied in the form of powders (particle size: $20 \mu \mathrm{m}$ ) were used as additives in the sludge tests. It is reported that $\mathrm{Ca}$ ion enhanced the methane production from anaerobic digestion ${ }^{15}$. The low-sodium-level Ca type zeolites were chosen for knowing effect for enhancing of methane production by $\mathrm{Ca}$ ion. The properties of the artificial zeolites used in the experiments are shown in Table 1.

2.2 Loading of batch reactors with zeolites First, $150 \mathrm{ml}$ of the sludge (10\% dry matter) was placed in a $200 \mathrm{ml}$ glass reactor. Glucose was added to the reactor at a final concentration of $2 \mathrm{~g} / \mathrm{l}$. A mineral solution containing $\mathrm{KH}_{2} \mathrm{PO}_{4} \quad(16 \mathrm{mg} / \mathrm{l})$, $\mathrm{MgCl}_{2} \cdot 6 \mathrm{H}_{2} \mathrm{O}(25 \mathrm{mg} / \mathrm{l}), \mathrm{CaCl}_{2} \cdot 2 \mathrm{H}_{2} \mathrm{O}(25 \mathrm{mg} / \mathrm{l})$, Fe-EDTA $(5 \mathrm{mg} / \mathrm{l}), \mathrm{CoCl}_{2} \cdot 6 \mathrm{H}_{2} \mathrm{O}(5 \mathrm{mg} / \mathrm{l})$, and $\mathrm{MnCl}_{2} \cdot 4 \mathrm{H}_{2} \mathrm{O}(5 \mathrm{mg} / \mathrm{l})$ was added at $200 \mathrm{ml} / \mathrm{l}$ to the reactor. $\mathrm{NH}_{4} \mathrm{Cl}$ was used for the ammonium source. Four different experiments were designed: (A) high ammonium concentration (3000 mg N/l) without zeolite, (B) high ammonium concentration (3000 mg N/l) with addition of Ca-type zeolite, (C) high ammonium concentration (3000 mg N/l) with addition of Fe-type zeolite, and (D) high ammonium concentration (3000 mg N/l) with addition of low-sodium-level Ca-type zeolite. The zeolites were added as $5 \%(\mathrm{w} / \mathrm{w})$ of the total liquid. The reactor was sealed with a rubber septum held in place by a plastic cover for the anaerobic conditions and a gas bag was connected to the bottle to measure the biogas volume. Nitrogen gas was added to remove the air from the glass reactor. Biogas production was periodically measured on the measuring scale of a plastic syringe. The reactors were then placed in a thermostated incubator at $35^{\circ} \mathrm{C}$. Once every 3 weeks, $50 \mathrm{ml}$ of digested sludge in the reactor was exchanged for new medium. 
2.3 Addition of cations To clarify the effect of the cations released from the $\mathrm{Fe}$ type zeolite, $\mathrm{Ca}$ ions and $\mathrm{Fe}$ ions were added to the sludge. Twenty $\mathrm{ml}$ of the sludge $(10 \%$ dry matter) was placed in a $50 \mathrm{ml}$ glass vial, and $1 \mathrm{~g}$ of Fe-type zeolite was added to the anaerobically digested sludge. $\mathrm{CaCl}_{2}$ was added at $950 \mathrm{mg} \mathrm{Ca}{ }^{2+} / \mathrm{l}$. Fe citrate was added at $15 \mathrm{mg} \mathrm{Fe} e^{3+} / \mathrm{l}$. Samples of the sludge were taken under the same ammonium-rich conditions as described in section 2.2. Five percent Fe-type zeolite, $950 \mathrm{mg} \mathrm{Ca}{ }^{2+} / 1,15 \mathrm{mg}$ $\mathrm{Fe}^{3+} / 1,950 \mathrm{mg} \mathrm{Ca}{ }^{2+} / 1+15 \mathrm{mg} \mathrm{Fe}{ }^{3+} / 1$, and no additive as the control were separately added to the vials, and incubated for 21 days at $35^{\circ} \mathrm{C}$. Each vial was sealed with a rubber septum held in place by a thin aluminum cover for the anaerobic conditions, and a 50 ml-volume plastic syringe was inserted into the vial to measure biogas volume. Nitrogen gas was added to remove the air from the glass vial. The vials were then placed in a thermostated incubator at $35^{\circ} \mathrm{C}$. After a 21day digestion period, the $\mathrm{NH}_{4}-\mathrm{N}$ (nitrogen in $\mathrm{NH}_{4}$ form) and methane concentrations were measured.

Standard deviations were evaluated by error propagation from triple applications of the sample.

2.4 Analytical methods The concentrations of $\mathrm{NH}_{4}^{+}, \mathrm{Ca}^{2+}, \mathrm{Mg}^{2+}, \mathrm{Na}^{+}$, and $\mathrm{K}^{+}$were determined using an ion chromatograph (DX120; Dionex Corp., Sunnyvale, CA, USA) and an IonPac CS12A column (Dionex) with a methyl-sulfonic acid solution $(18 \mathrm{mmol})$ as the mobile phase. The samples for ion chromatography were separated into supernatant and sediments by centrifuge $(10,000 \mathrm{rpm}, 10 \mathrm{~min})$. The concentrations of organic acid were determined using the ion chromatograph (DX120) and an IonPac ICEAS1 column (Dionex) with a heptafluorobutyric acid solution $(1 \mathrm{mmol})$ as the mobile phase. The composition of the biogas was determined using a gas chromatograph (GC-8A; Shimadzu Corp., Kyoto, Japan) with a thermal conductivity detector equipped with a steel column $(3 \mathrm{~m} \times$ $3 \mathrm{~mm}$ ) packed with Porapak Q (Shinwa Chemical Industries, Ltd., Kyoto, Japan) at $90^{\circ} \mathrm{C}$, and argon was used for the carrier gas with a gas flow pressure of $100 \mathrm{kPa}$. Biogas was sampled from the gas bag connected to the bottles or the top of the vials using a syringe attached to a needle. The volume of methane was obtained by the volume of increased biogas multiplied by the concentration of methane detected by gas chromatograph.

\subsection{Quantification of immobilized microbes} using real-time PCR analysis DNA was extracted from the liquid of four types (A, B, C, D) in the reactors after completion of the experiments. Real-time polymerase chain reaction (PCR) analysis was conducted using an ABI PRISM ${ }^{\circledR} 7000$ Sequence Detection System (Applied Biosystems, Foster City, CA, USA) and a TaqMan ${ }^{\circledR}$ Universal PCR Master Mix (Applied Biosystems). The amplifying primer set S-P-MArch-0348-S-a-17 and S-DArch-0786-A-a-20 and the double dye probe S-P-MArch-0515-S-a-25 were used for the methanogens ${ }^{16,17)}$. The amplifying primer set S-F-Msaet-0387-S-a-21 and S-F-Msaet-0573A-a-17 and double dye probe S-F-ZMsaet0540-A-a-31 were used for the Methanosaeta spp. ${ }^{17)}$. The amplifying primer set S-F-Msar0450-S-a-19 and S-F-Msar-0588-A-a-20 and double dye probe S-F-Msar-0544-A-a-31 were used for the Methanosarcina spp. ${ }^{18)}$. The amplifying primer set S-F-Mbac-0398-S-a-20 and S-F-Mbac-0578-A-a-22 and double dye probe S-F-ZMbac-0526-A-a-33 were used for the Methanobacterium spp. ${ }^{18)}$. The real-time PCR amplification followed a three-step PCR (40 cycles) with $20 \mathrm{~s}$ denaturation $\left(95^{\circ} \mathrm{C}\right), 20$ $\mathrm{s}$ annealing $\left(55^{\circ} \mathrm{C}\right)$, and $120 \mathrm{~s}$ elongation $\left(72^{\circ} \mathrm{C}\right)$. Quantitative measurements by realtime PCR were conducted in quadruplicate.

\section{RESULTS}

3.1 Effect of Fe-type zeolite on methane production from batch reactors Figure 1 shows the cumulative methane production from the batch reactors with and without zeolite addition. The methane production from the reactor with Fe-type zeolite addition was higher than those with Ca-type zeolite, with low-sodium-level Ca-type zeolite, and without zeolite. The methane production with Ca-type zeolite addition showed no improvement compared to that without 


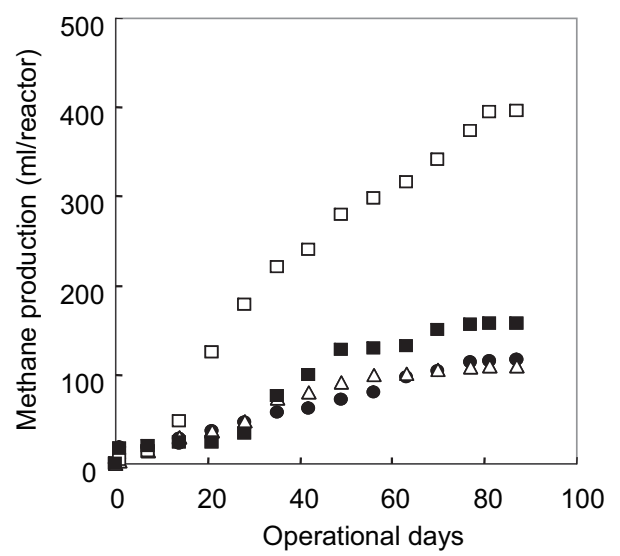

Fig. 1 Methane production from reactors with and without artificial zeolites. The closed circles show methane production without additives, the open squares show that with Fe-type zeolite addition, the open triangles show that with Ca-type zeolite addition, and the closed squares show that with low-sodium-level Ca-type zeolite addition.

zeolite. The methane production with lowsodium-level Ca-type zeolite addition was 1.36 times higher than that without zeolite at day 80 . The cumulative methane production with Fe-type zeolite addition was approximately 4 times higher than that without zeolite at day 80 .

3.2 Cation concentrations Table 2 shows the ion concentrations of the reactors after anaerobic digestion. With zeolite addition, the ammonium ion concentration lowered by about $500 \mathrm{mg} / \mathrm{l}$ compared to that without zeolite. The amount of decrease was almost the same among the different zeolites. The Fe concentrations with Ca-type zeolite and low-sodium-level Ca-type zeolite additions were less than those with Fe-type zeolite

Table 2 Ion concentrations of the reactors after anaerobic digestion

\begin{tabular}{lrrrrrrr}
\hline & $\begin{array}{l}\mathrm{NH}_{4}-\mathrm{N} \\
(\mathrm{mg} / \mathrm{l})\end{array}(\mathrm{mg} / \mathrm{l})$ & $\mathrm{Ca}^{2}+$ & $\mathrm{K}+$ & $\mathrm{K} / \mathrm{l})$ & $(\mathrm{mg} / \mathrm{l})$ & $\begin{array}{c}\mathrm{Fe}^{3}+ \\
(\mathrm{mg} / \mathrm{l})\end{array}$ & $\mathrm{pH}$ \\
\hline $\begin{array}{l}\text { Before } \\
\text { experiment }\end{array}$ & 1127 & 15 & 47 & 30 & $<0.5$ & 7.2 \\
Fe-type zeolite & 1067 & 733 & 937 & 257 & 32 & 7.0 \\
Ca-type zeolite & 1047 & 1129 & 753 & 130 & $<0.5$ & 7.2 \\
Low sodium level & 986 & 257 & 1406 & 100 & $<0.5$ & 7.1 \\
$\begin{array}{l}\text { Ca- type zeolite } \\
\text { No additives }\end{array}$ & 1581 & 36 & 50 & 16 & 21 & 6.5 \\
\hline
\end{tabular}

addition and with no additive. Fe-type zeolite also released $\mathrm{Ca}^{2+}$ ions. The $\mathrm{Ca}^{2+}$ ion concentration with the zeolite additions was 10 times higher than that without zeolite. The $\mathrm{pH}$ value without zeolite was 6.5, whereas that with the zeolite additions was almost 7 .

3.3 Organic acid concentrations Figure 2 shows the concentrations of organic acids after anaerobic digestion. The acetate concentrations with the zeolite additions showed a larger decrease compared to those without zeolite. In particular, the acetate concentration with Fe-type zeolite addition was very low compared to those with Ca-type and low-sodium-level Ca-type zeolite additions. The propionate concentrations with the zeolite additions did not differ significantly. The butyrate concentrations with the zeolite additions were lower than those without zeolite. The butyrate concentration with Fe-type zeolite addition was less than half of those with Ca-type zeolite and low-sodium-level Ca-type zeolite additions. The lactate concentrations with the zeolite additions were higher than those without zeolite.
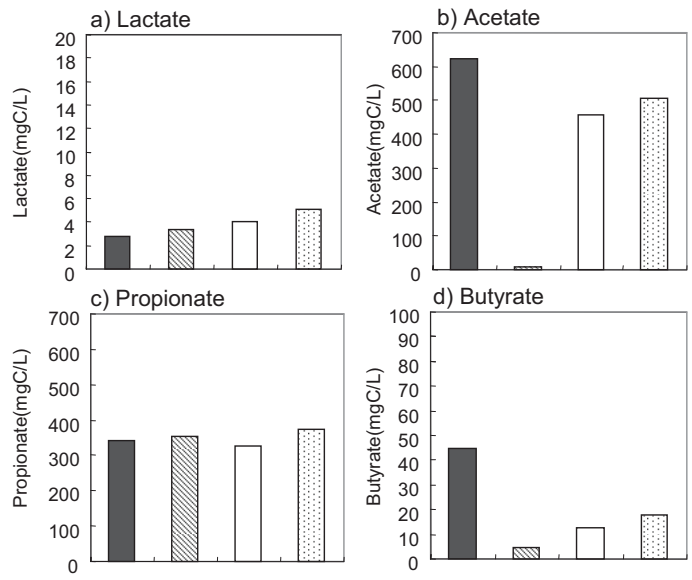

Fig. 2 Organic acid concentrations in the reactors on the final day of operation. The closed bars show the concentrations without additives, the diagonally shaded bars show those with Fe-type zeolite addition, the open bars show those with Ca-type zeolite addition, and the dotted bars show those with low-sodium-level Ca-type zeolite addition. 


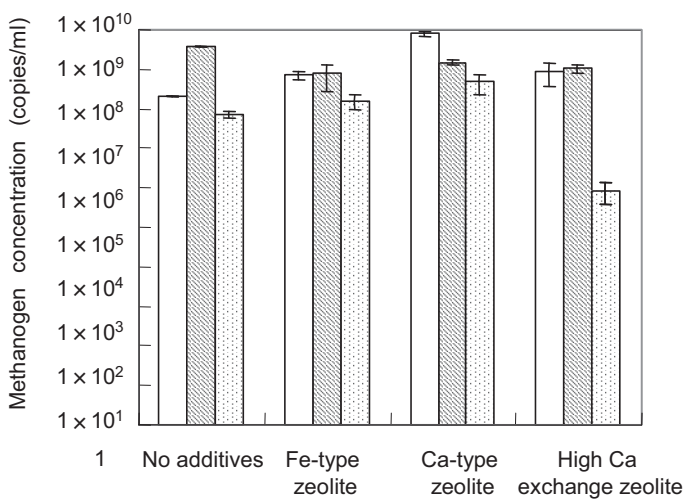

Fig. 3 Concentrations of methanogens in the reactors measured by real-time PCR. The open bars show Methanosarcina spp., the diagonally shaded bars show Methanobacterium spp., and the dotted bars show Methanosaeta spp. The bars indicate standard deviations.

3.4 Archaeal community Figure 3 shows the results of real-time PCR. The concentrations of Methanosarcina spp. with and without zeolite ranged from $1.2 \times 10^{8}$ to $8.0 \times 10^{9} \mathrm{copies} / \mathrm{ml}$, those of Methanobacterium spp. ranged from $7.8 \times 10^{8}$ to $3.9 \times 10^{9}$ copies/ $\mathrm{ml}$, and those of Methanosaeta spp. ranged from $8.4 \times 10^{5}$ to $4.8 \times 10^{8} \mathrm{copies} / \mathrm{ml}$. The concentrations of Methanosarcina spp. with zeolite were higher than that without zeolite, and that with the Ca-type zeolite addition was highest than that with Fe-type zeolite addition and with low-sodium-level Ca-type zeolite. The concentrations of Methanobacterium spp. with zeolite were lower than that without zeolite, but that were not different among zeolites addition condition. The concentrations of Methanosaeta spp. with low-sodium-level Ca-type zeolite additions was lower than other reactors.

\subsection{Effect of $\mathrm{Fe}$ and $\mathrm{Ca}$ ions on methane} production Figure 4 shows the methane production during 21 days of anaerobic digestion with $\mathrm{Fe}^{3+}$ or $\mathrm{Ca}^{2+}$ ion addition. With the addition of Fe-type zeolite, methane production was higher than that with $\mathrm{Ca}^{2+}$ and $\mathrm{Fe}^{3+}$ ions. Comparing the methane production between the $\mathrm{Fe}^{3+}$ ion addition and the $\mathrm{Ca}^{2+}$ ion addition, methane production with the $\mathrm{Fe}^{3+}$ ion addition was enhanced to a greater extent than that with the $\mathrm{Ca}^{2+}$ ion

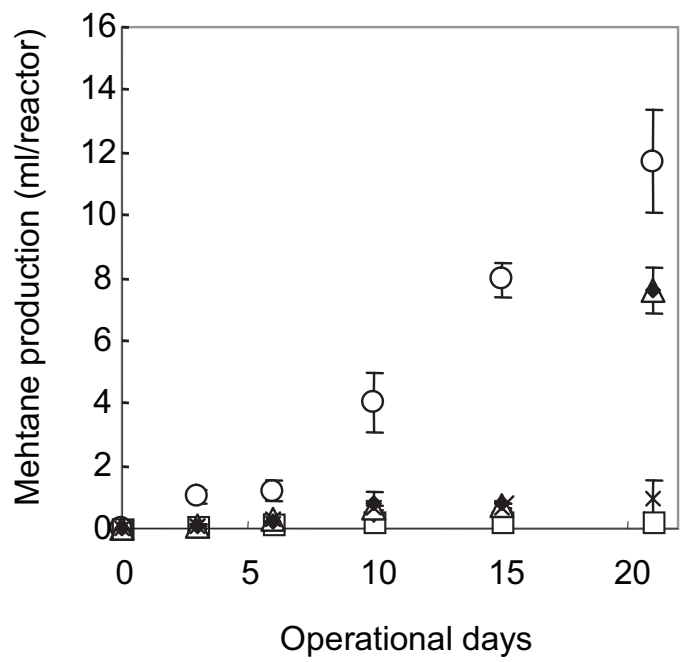

Fig. 4 Effect of iron and calcium ions on methane production under ammonium-rich conditions (3000 mg N/l). The open squares show methane production without additives, the open circles show that with Fe-type zeolite addition, the open triangles show that with the addition of $\mathrm{Fe}^{3+}$ and $\mathrm{Ca}^{2+}$ ions, the closed rhombuses show that with the addition of $\mathrm{Fe}^{3+}$ ions, and the crosses show that with the addition of $\mathrm{Ca}^{2+}$ ions. The bars indicate standard deviations.

Table 3 Organic acid concentration after 21 days of anaerobic digestion with $\mathrm{Fe}^{3+}$ or $\mathrm{Ca}^{2+}$ ion addition

\begin{tabular}{lrrrr}
\hline & $\begin{array}{c}\text { Acetate } \\
(\mathrm{mg} / \mathrm{l})\end{array}$ & $\begin{array}{r}\text { Propionate } \\
(\mathrm{mg} / \mathrm{l})\end{array}$ & $\begin{array}{r}\text { Butyrate } \\
(\mathrm{mg} / \mathrm{l})\end{array}$ & $\begin{array}{r}\mathrm{NH}_{4} \mathrm{~N} \\
(\mathrm{mg} / \mathrm{l})\end{array}$ \\
\hline $\begin{array}{l}\text { No additives } \\
\text { Addition of }\end{array}$ & 741 & 117 & 204 & 1531 \\
$\quad \begin{array}{l}\text { Fe-type zeolite } \\
\text { Addition of }\end{array}$ & 0 & 0 & 0 & 1095 \\
$\mathrm{Fe}^{3+} \& \mathrm{Ca}^{2+}$ & 1.9 & 156 & 0 & 1538 \\
${\text { Addition of } \mathrm{Fe}^{3+}}^{3+}$ & 3.7 & 184 & 0 & 1552 \\
Addition of $\mathrm{Ca}^{2+}$ & 674 & 78 & 267 & 1571 \\
\hline
\end{tabular}

addition. Table 3 shows the organic acid concentration after 21 days of anaerobic digestion with $\mathrm{Fe}^{3+}$ or $\mathrm{Ca}^{2+}$ ion addition. The acetate concentration without zeolites and with $\mathrm{Ca}^{2+}$ ions was 100 times higher than those with $\mathrm{Fe}$-type zeolite, $\mathrm{Fe}^{3+}$ and $\mathrm{Ca}^{2+}$ ions, and $\mathrm{Fe}^{3+}$ ions. The $\mathrm{pH}$ values of each condition except without no addition were almost 7 .

\section{DISCUSSION}

The results (Fig. 2) obtained for acetate concentration without zeolite addition showed 
that ammonium inhibition during anaerobic digestion could lead to acetate accumulation. Poggi-Varaldo (1991) reported that the specific acetate-uptake rate in anaerobic digestion was affected by the concentration of un-ionized ammonia ${ }^{19}$. The ammonium ion concentration decreased with the addition of zeolites (Table 2). Only Fe-type zeolite enhanced methane production (Fig. 1). Tada et al. (2005) reported that $\mathrm{Ca}^{2+}$ ions released from natural mordenite improved methane production from ammonium-rich organic waste during anaerobic digestion ${ }^{15}$. However, the present artificial Ca-type zeolite did not improve methane production (Fig. 1). It is considered that differences in the exchanged ions and crystal structures of the zeolites caused the different results. The total carbon of the glucose added to the reactor was 0.28 g. The theoretical methane production from glucose added to the reactor was $261 \mathrm{ml}$. The methane production with Fe-type zeolite addition was 1.5 times higher than the theoretical value. These results suggest that Fe-type zeolite enhanced self-degradation of the anaerobically digested sludge.

The acetate concentration decreased with the addition of $\mathrm{Fe}^{3+}$ ions, but did not decrease with the addition of $\mathrm{Ca}^{2+}$ ions (Table 3). Furthermore, the methane production showed weak improvement with the addition of $\mathrm{Fe}^{3+}$ ions, although the ammonium ion concentration did not decrease (Fig. 4, Table 2 ). It has been reported that the addition of iron improved methane production from acetate $^{20)}$. Hoban et al. (1979) reported that the optimum soluble iron concentration was between $0.2 \mathrm{mM}(11.17 \mathrm{mg} / \mathrm{l})$ and $2 \mathrm{mM}$ $(111.7 \mathrm{mg} / \mathrm{l})$ for conversion of acetic acid to methan $\mathrm{e}^{20}$. In our results, the concentration of $\mathrm{Fe}^{3+}$ ions released from Fe-type zeolite after digestion was included in the optimum concentrations (Table 2). Fe-type zeolite addition could enhance biogas production through ammonium exchange and the release of $\mathrm{Fe}^{3+}$ and $\mathrm{Ca}^{2+}$ ions.

In the case of Fe-type zeolite, not only acetate but also propionate and butyrate were not detected after 21 days of anaerobic digestion (Table 2). Propionate and butyrate can be degraded only when acetate and especially hydrogen are effectively eliminated by the methanogens. Van Schie et al. (1999) reported that Syntrophomonas wolfeii, known as a degrader of propionate and butyrate, adhered more on the $\mathrm{Fe}^{3+}$ surface of glass ${ }^{21}$. It is considered that $S$. wolfeii increased at a higher rate with Fe-type zeolite addition than with the other zeolite additions.

It has been reported that Methanosaeta spp. decreased with increasing ammonium concentration (Sawayama et al., 2004). Angenent et al. (2002) reported that Methanosarcina decreased when the ammonia-N level increased to $3600 \mathrm{mg} / \mathrm{l}$ from $2000 \mathrm{mg} / \mathrm{l}^{22)}$. The growth of Methanosarcina barkeri was resistant to ammonia in shortterm studies comparing it with Methanospirillum hungatei and Methanobacterium bryantii ${ }^{6}$. Methane production by $M$. barkeri with $200 \mathrm{mM} \mathrm{NH}_{4} \mathrm{Cl}$ was inhibited to about $50 \%$ of that without $\mathrm{NH}_{4} \mathrm{Cl}$, and methane production by $M$. bryantii with $200 \mathrm{mM} \mathrm{NH} \mathrm{NH}_{4} \mathrm{Cl}$ was weakly inhibited by $10 \%$. These results by Sprott et al. (1986) show that M. barkeri could grow under $200 \mathrm{mM} \mathrm{NH} \mathrm{NH}_{4} \mathrm{Cl}$ conditions, but the production of methane from the acetate was inhibited $^{6}$. In our results, the quantities of Methanobacterium spp. did not differ among the zeolite addition conditions, but the methane production was different among the conditions (Fig. 3). In addition, the acetate accumulation was observed in the reactor with Ca-type zeolite additions although the quantities of Methanosarcina spp. was highest in other reactors (Fig. 2). These results and reports suggest that not quantity of methanogen but methanogenic activity is affected by zeolite addition under ammoniumrich conditions. Gallert et al. (1998) reported that acetate and propionate were detected at ammonia concentrations higher than 1082 $\mathrm{mg} / \mathrm{l}$ in mesophilic digestion ${ }^{2}$. In the present study, the ammonium concentration decreased with Fe-type zeolite addition (1095 mg/l) (Table 3). Lay et al.(1998) reported that the methane production rate by differential $\mathrm{NH}_{4}$ $\mathrm{N}$ concentrations, the methane production were marked a sharp decline when the $\mathrm{NH}_{4}$ $\mathrm{N}$ concentration increasing more than 1200 $\mathrm{mg} / \mathrm{l}^{22)}$. In this study, the $\mathrm{NH}_{4}-\mathrm{N}$ concentration was decreased lower than $1200 \mathrm{mg} / \mathrm{l}$ by addition of zeolites. The removal of ammonium 
ions by Fe-type zeolite prevents propionate accumulation during anaerobic digestion under ammonium-rich conditions.

\section{CONCLUSIONS}

The addition of Fe-type zeolite, which made from waste coal ash, is effective to enhance the methane production about four times higher than that without zeolite from anaerobic digestion under ammonium-rich conditions. Acetate was not accumulated during anaerobic digestion of ammonium-rich organic waste with Fe-type zeolite although that was with the other type zeolites. The methanogen community with Fe-type zeolite was almost the same as that with Ca-type zeolite. Comparing the addition of Fe-type zeolite and the addition of iron ions, the addition of Fe-type zeolite is more effective enhancing the methane production from anaerobic digestion under ammonium-rich conditions than the addition of iron ions.

Fe-type zeolite is considered to play two roles in anaerobic digestion; namely, supplying iron to the anaerobic microbes, and decreasing the ammonium concentration.

\section{References}

1 ) Mata-Alvarez, J., Mace, S., and Llabres, P.: Anaerobic digestion of organic solid wastes. An overview of research achievements and perspectives, Biores. Technol., 74, 3-16 (2000)

2 ) Gallert, C., Bauer, S., and Winter, J.: . Effect of ammonia on the anaerobic degradation of protein by a mesophilic and thermophilic biowaste population, Apple. Microbiol. Biotechnol, 50, 495-501 (1998)

3 ) Kayhanian, M.: Ammonia inhibition in high-solids biogasification: An overview and practical solutions, Environ. Technol., 20, 355-365 (1999)

4 ) Angelidaki, I. and Ahring, B.K.: Anaerobic thermophilic digestion of manure at different ammonia loads: Effect of temperature, Water Res., 28, 727731 (1994)

5 ) Truper, H. G. and Pfenning, N.: Characterization and identification of the anoxygenic phototrophic bacteria. in "The
Prokaryotes", ed. By M.P. Starr, H. Stolp, H.G. Truper, A. Balows and HG Schlegel, Springer-Verlag, Berlin, Heidelberg, New York, 1, 299-312 (1981)

6 ) Sprott, G.D. and Patel, G.B.: Ammonia toxicity in pure cultures of methanogenic bacteria, System. Appl. Microbiol., 7, 358-363 (1986)

7 ) Hendrinksen, H.V. and Ahring, B.K.: Effects of ammonia on growth and morphology of thermophilic hydrogen-oxidizing methanogenic bacteria, FEMS Microbiol. Ecol., 85, 241-246 (1991)

8 ) McCarty, P.L. and McKinney, R.E.: Salt toxicity in anaerobic digestion, J. Water Poll. Cont. Fed., 33 , 399-415 (1961)

9 ) Hobson, P.N. and Shaw, B.G.: Inhibition of methane production by Methanobacterium formicicum, Water Res., 10, 849-852 (1976)

10) Demeestere, K., Smet, E., Van Langenhove, H., and Galbacs, Z.: Optimization of magnesium ammonium phosphate precipitation and its applicability to the removal of ammonia, Environ Technol, 22, 1419-1428 (2001)

11) Sawayama, S., Tsukahara, K., and Yagishita, T.: Wastewater treatment and poly-Bhydroxybutyrate production using/lighted upflow anaerobic sludge blanket method, J. Biosci. Bioeng., 87, 683-689 (1999)

12) Milan, Z., Sanchez, E., Weiland, P. Borja, R. Martin, A., and Ilangovan, K.: Influence of different natural zeolite concentrations on the anaerobic digestion of piggery waste, Biores. Technol., 80, 37-43 (2001)

13) Angelidaki, I. and Ahring, B.K.: Effect of the clay mineral bentonite on ammonia inhibition of anaerobic thermophilic reactors degrading animal waste, Biodegradation, 3, 409-414 (1993)

14) Hansen, K.H., Angelidaki, I., and Ahring, B.K.: Improving thermophilic anaerobic digestion of swine manure, Water Res., 33 (8), 1805-1810 (1999)

15) Tada, C., Yang, Y., Hanaoka, T., Sonoda, A., Ooi, K., and Sawayama, S.: Effect of natural zeolite on methane production for anaerobic digestion of ammonium rich organic sludge, Biores. Technol., 96, 459-464 (2005)

16) Takai, K. and Horikoshi, K.: Rapid detection and quantification of members of the 
Archaeal community by quantitative PCR using fluorogenic probes, Appl. Environ. Microbiol., 66, 5066-5072 (2000)

17) Sawayama, S., Tada, C., Tsukahara, K., and Yagishita, T.: Effect of ammonium addition on methanogenic community in a fluidized bed anaerobic digestion, J. Biosci. Bioeng., 97, 65-70 (2004)

18) Poggi-Varaldo, H.M., Tingley, J., and Oleszkiewicz, J.A.: Inhibition of growth and acetate uptake by ammonia in batch anaerobic digestion, J. Chem. Technol. Biotechnol., 52, 135-143 (1991)

19) Hoban, D.J. and van den Berg, L.: Effect of iron on conversion of acetic acid to methane during methanogenic fermentations, J. Appl. Bacteriol., 47, 153-159
(1979)

20) Van Schie, P.M. and Fletcher, M.: . Adhesion of biodegradative anaerobic bacteria to solid surfaces, Appl. Environ. Microbiol., 65, 5082-5088 (1999)

21) Angenent, L.T., Sung, S., and Raskin, L.: Methanogenic population dynamics during startup of a full-scale anaerobic sequencing batch reactor treating swine waste, Water Res., 36, 4648-4654 (2002)

22) Lay, J.J., Li, Y. Y., and Noike, T.: The influence of $\mathrm{pH}$ and ammonia concentration on the methane production in high-solids digestion processes, Water Environ. Res., 70, 1075-1082 (1998)

(Submitted 2006. 1. 5)

(Accepted 2006. 4. 18) 